\title{
EFFECT OF DIET EXTRUDED TYPE ON GROWTH PERFORMANCE, FEED UTILIZATION AND ECONOMIC EFFICIENCY OF NILE TILAPIA IN COMMERCIAL FARMS
}

\author{
R.M. Abou-Zied \\ Faculty of Agriculture, Fayoum University, Egypt.
}

\section{SUMMARY}

\begin{abstract}
$\mathrm{T}$ his study aimed to evaluate the effect of extruded diets (floating and sinking) on growth parameters, feed utilization and economic efficiency of Nile tilapia (Oreochromisniloticus) cultured in commercial farms. A total number of (100000) mono sex Nile tilapiafingerlings of 5.27 $\pm 0.01 \mathrm{~g}$ initial body weight in average were allotted randomly into four earthen ponds (two feddan/each). Two diets were used extruded floating diet (EFD) and extruded sinking diet (ESD), from zoo control company. The diets contained the same level of protein, carbohydrate and fat as formulation and ingredients of the experimental diets were the same. Each diet contained in average $27.37 \% \mathrm{CP}$ and $4.57 \mathrm{kcal} / \mathrm{g}$ GE. Fish were fed pelleted extruded diet type at a rate of $3 \%$ of the total body weightand was adjusted every month intervals until harvesting. Results cleared that final mean weight and weight gain were significantly $(\mathrm{P} \leq 0.05)$ better with EFD, while lower values were recorded with ESD, but daily gain and specific growth rate insignificantly affected by diet type.Feed intake was significantly decreased with EFD. FCR values were significantly better with EFD than ESD. Survival rates insignificantly affected and ranged between 87.23 and 92.10\%. Net returns and profit index were significantly high with EFD than sinking diet.

In conclusion regarding to final weight, survival rate, net returns and profit index, the EFD was best feed if served suitable environmental condition specially low wind speed and lack of birds.
\end{abstract}

Keywords: Nile tilapia, extruded floating, sinking diet, growth performance, feed utilization and economic efficiency.

\section{INTRODUCTION}

Aquaculture in Egypt witnessed a significant and rapid expansion over the last few years. While semiintensivefish culture in earthen ponds is the most important farming system in Egypt, recent years have witnessed a rapid development of intensive systems in both tanks and cages in addition to farming in the desert.As a result, farmed fish production increased fromonly 63,895 tonnes in 1992, representing $18.5 \%$ of total Egyptian fishproduction to reach 1,017,738 tonnes in 2012, contributing 74\% tototal production (FAO, 2013and GAFRD, 2014). Meanwhile the farmedarea has increased from about 42,000 ha in 1999 (El-Sayed, 1999) to120, 000 ha in 2012 (GAFRD, 2014).

There are few species used in aquaculture. Some of which are native while few are introduced. However, three groups compromise more than $95 \%$ of aquaculture production and their percentage contributions total production are tilapias (75.54\%), mullet $(12.74 \%)$ and carps $(6.59 \%)$. There are promising practices for African catfish farming. While tilapia is steadily increasing, carps are declining due to marketing problems (GAFRD, 2012). Tilapia has the advantage of being quite tolerant of various water qualities, even a slight salt content (not all species, but several fast-growing kinds of tilapia). And they require no antibiotics if done right, so it can be the ideal fish for a developing economy, as long as labor and land prices are low.

Aquaculture plays a major role in supplying affordable animal protein for Egyptians and current policies support intensification and higher production levels. Egypt is among the ten largest producers of farmed fish (mostly tilapia) globally (FAO 2012).

The artificial feeding is considered supplementary feeding to help the natural growth of fish quickly during a culture period which varies depending on the type of fish farmed. Macfadyen et al. (2011) reports that there are 25 fish feed mills in Egypt, producing more than 300,000 Mtof fish feed each year. Increasing world market prices of raw materials resultedin an increase of feed prices with $200-250 \%$ over the last $6-7$ years (Macfedyen et al., 2012). 


\begin{abstract}
Abou-Zeid
El-Sayed et al.(2015) reported that about $90 \%$ of Egyptian aquafeeds are produced by the private sector in the form of conventionally pressed, pelleted feeds (80-85\%) and extruded feeds (15-20\%). Extruded (expanded, or floating) aquafeed technology was introduced into Egypt in the mid-1990s. Since 2001, a number of commercial, private feed manufacturers have added production lines for extruded feed production to complement their traditional production lines. The market demand for extruded feed is increasing, despite the significantly higher prices. Tilapia farmers prefer this type of feed because it is better digested, converted and assimilated by the fish (El-Sayed, 2007). Indeed, approximately 40 percent of surveyed tilapia farmers use extruded feeds.

Currently there are 5 mills producing extruded fish feed; representing $20-25 \%$ of total fish feed production. Feed mills also provide a wide range of different feed formulations to match the requirements of different stages of the growth cycle (e.g. different protein content). In addition to the registered mills, there are around 50 small-scale pelletizing units, each producing 3000-4000 t/year and with total annual production of 120,000 to 240,000t (El-Naggar et al., 2011). These pelletizing units use simple technology and may not be equipped with air driers. They offer the service of compressing farmers' feed ingredients for about EGP 100-150/t (El-Naggar et al., 2011).
\end{abstract}

\title{
MATERIALS AND METHODS
}

This study was conducted at a commercial farm located in WadiEl-Rayan region, Fayoum Governorate, Egypt, it started at 11/4/2014 and terminated at the 21/11/2014 (223 days period).

A total number of (100000) mono sex Nile tilapia (Oreochromisniloticus) fingerlings of $5.27 \pm 0.01 \mathrm{~g}$ initial body weight in average that obtained from nursing pond located at the same farm. The fish were allotted randomly into four earthen pond (twofeddan/each). Accordingly 25000 fish were stocked/each earthen pond.

Two diets were used, extruded floating diet (EFD) and extruded sinking diet (ESD), from zoo Control Company. The diets contained the same level of protein, carbohydrate and fat as formulation and ingredients of the experimental diets were the same. Each diet was analyzed according to AOAC (1990) and contained in average $27.37 \% \mathrm{CP}$ and $4.57 \mathrm{kcal} / \mathrm{g} \mathrm{GE}$ as indicated in Table (1). Fish were fed pelleted extruded diet type at a rate of $3 \%$ of the total body weight until harvesting. Fingerlings were fed 3 times daily at 8 and 11 am and $4 \mathrm{pm} 6$ days/week. Extruded floating diets were thrown from pond bridge to the inside rectangular wooden frame on the surface of pond water to prevent feed spread on pond by wind, and feeders were covered with invisible plastic net to protect feed from birds. Extruded sinking diets were thrown from Pond Bridge on a wooden feeders fixed bottom the water's surface by about $25-30 \mathrm{~cm}$ with mud from plastic jerry cans. Feed amount was adjusted every month intervals.

\section{Parameters measurements:}

At the end of the experiment, growth parameters and survival rate were measured as follows:

- Weight gain = Final weight - Initial weight (Effiong et al., 2009).

- Daily gain = Weight gain, g/period in days. (Effiong et al., 2009).

Table (1): Proximate analysis of extruded diet type used (on DM basis).

\begin{tabular}{|c|c|c|}
\hline \multirow{2}{*}{ Items } & \multicolumn{2}{|c|}{ Extruded diet } \\
\hline & Floating & Sinking \\
\hline $\mathrm{DM}$ & 90.21 & 89.85 \\
\hline Crude protein, $\mathrm{CP}$ & 27.24 & 27.51 \\
\hline Ether extract, EE & 7.43 & 7.82 \\
\hline Ash & 8.94 & 8.68 \\
\hline Crude fiber, $\mathrm{CF}$ & 4.86 & 4.93 \\
\hline Nitrogen free extract. NFE ${ }^{1}$ & 51.53 & 51.06 \\
\hline $\mathrm{GE}, \mathrm{kcal} / \mathrm{g}^{2}$ & 4.555 & 4.591 \\
\hline
\end{tabular}

${ }^{1}$ Calculated by differences, $N F E=O M-(C P+E E+C F)$.

${ }^{2}$ Calculated according to NRC (1993). 
- Specific growth rate $(S G R, \%)=100$ (ln Final weight-ln Initial weight)/period in days, where $\ln$ is the natural log. (Effiong et al., 2009).

- Feed conversion ratio $(F C R)=$ feed offered / weight gain (Effiong et al., 2009).

- Survival rate $(S R) \%=$ Final number of fish /Initial number of fish $\times 100$. (Charo-Karisa et al., 2006).

A simple economic analysis was used to assess the cost effectiveness of diets used in the feed trial. The cost of feed was calculated using market prices taken into consideration the cost of feed and the transport fare with the assumption that all other operating costs remained constant (e.g. cost of constructing, cost of fingerlings and labour).

- Profit index $(P I)=$ Value of fish produced/ feed costs (Abu et al., 2010).

\section{Water quality parameters:}

Water temperature, $\mathrm{pH}$, dissolved oxygen (DO) and total ammona throughout experimental periods were measured periodically every week in the morning and at noon by centigrade thermometer, Orion digital pH meter model 201, HANNA HI 9146 oxygen meter, HACH test kit ammonia mid-range 0-3 mg/L model NI-8.

\section{Statistical Analysis:}

Data were statistically analyzed in a one- way analysis of variance using SPSS (2012). Mean of treatments were compared by Duncan (1955) multiple range test when the variance analysis was significant.

\section{RESULTS AND DISCUSSION}

\section{Water quality:}

Results of water quality parameters of Nile tilapia as affected by receiving extruded diets type during the experimental period (223 days) are presented in Table (2). In general, average of water temperature was 28.5 for both treatments. Thisresultis in agreement with those of Boyd, (1983); Jobling, (1983) and Abdel -HaKim et al.(2000), who found that the optimum temperature ranged between 15 and $30^{\circ} \mathrm{C}$ for Nile tilapia (Oreochromisniloticus). Averages of $\mathrm{pH}$ values were 7.79 and 7.74 for EFD and ESD, respectively, these values was suitable for Nile tilapia.

Table (2): Water quality parameters recorded during the experimental period.

\begin{tabular}{|c|c|c|c|c|c|c|c|c|}
\hline \multirow{2}{*}{ Month } & \multicolumn{2}{|c|}{ Temperature, ${ }^{\circ} \mathrm{C}$} & \multicolumn{2}{|c|}{$\mathrm{pH}$} & \multicolumn{2}{|c|}{$\begin{array}{c}\text { Dissolved oxygen, } \\
\mathrm{mg} / \mathrm{l}\end{array}$} & \multicolumn{2}{|c|}{ Ammonia, mg/l } \\
\hline & EFD & ESD & EFD & ESD & EFD & ESD & EFD & ESD \\
\hline April & 27 & 27 & 7.84 & 7.87 & 10.89 & 10.80 & 0 & 0 \\
\hline May & 28 & 28 & 7.73 & 7.78 & 10.57 & 10.73 & 0 & 0 \\
\hline June & 29 & 29 & 7.59 & 7.64 & 10.64 & 10.31 & 0.2 & 0.2 \\
\hline July & 30 & 30 & 7.68 & 7.78 & 9.94 & 9.72 & 0.2 & 0.2 \\
\hline August & 30 & 30 & 7.83 & 7.88 & 9.35 & 8.67 & 0.2 & 0.4 \\
\hline September & 29 & 29 & 7.82 & 7.52 & 8.48 & 7.64 & 0.4 & 1.0 \\
\hline October & 28 & 28 & 7.91 & 7.74 & 8.94 & 7.50 & 0.4 & 1.60 \\
\hline November & 27 & 27 & 7.88 & 7.69 & 8.83 & 7.20 & 0.6 & 2.0 \\
\hline Average & 28.5 & 28.5 & 7.79 & 7.74 & 9.71 & 9.07 & 0.25 & 0.66 \\
\hline
\end{tabular}

The concentrations of dissolved oxygen (mg/L) for EFD and ESD were 9.71 and $9.07 \mathrm{mg} / \mathrm{L}$, respectively. These values are beneficial to fish culture and indicate that water dissolved oxygen was suitable. These results are in agreement with Boyd (1992), who reported that levels of dissolved oxygen above $4 \mathrm{ppm}$ is considered a limiting factor, below which, fish may live but can't feed or grow well.

The average concentrations of total ammonia were 0.25 and $0.66 \mathrm{mg} / \mathrm{l}$ for EFD and ESD, respectively these value equal 0.012 and 0.033 unionized ammonia calculated according to Florida Department of Environmental Protection (2001). The hightotal ammonia concentration in ponds fed ESD compared with ponds fed EFD is a result of analyzed part of sinking diets and mixed with mud, raising total ammonia (which within safe limits), these results are far than toxic level of unionized ammonia (2 mg/l) that reported by the European Inland Fisheries Advisory Commission (1993).

In general water quality parameters measured were suitable for the normal growth of tilapia. Such trend was mentioned by Stickney (1986); Tahoun (2007) and Khalfalla et al. (2008). 


\section{Growth performance:}

Data of growth performance are presented in Table (3). There were no significant differences $(\mathrm{P} \leq 0.05)$ in daily gain and SGR among fish fed different diets.

Final mean weight and weight gain were significantly $(\mathrm{P} \leq 0.05)$ better with extruded floating diet, while lower values were recorded with extruded sinking diet. Improved growth of fish fed extruded floating diet may be due to the presence of pelleted floating diet above the water surface, which can fish taken and benefit from it as well as the fish movement and activity as a result of rise of the water surface to feed, which works to improve digestion. But the extruded sinking diet on the feeder lose part of them as a result of movement of fish and download to the bottom of pond and mixed with mud and fish nor benefit them as well as change the water properties as a result of the accumulation of feed waste analyzed in water causing increased total ammonia concentration in ponds fed ESD compared with ponds fed EFD (which within safe limits), which affect the fish growth rates. These resultsare agreements with the results obtained by Hematzade et al. (2013) with rainbow trout and disagreed with that obtained by Kristiansen and Ferno (2007).

Table (3): Effect of extruded diet type on growth performance parameters of Nile tilapia reared in commercial earthen ponds.

\begin{tabular}{lccc}
\hline \multicolumn{1}{c}{ Parameters } & \multicolumn{2}{c}{ Extruded diet } & SED \\
\cline { 2 - 3 } & Floating & Sinking & \\
\hline Initial mean body weight, g & 5.27 & 5.26 & 0.03 \\
Final mean body weight, g & $303.71^{\mathrm{a}}$ & $276.67^{\mathrm{b}}$ & 8.87 \\
Total gain, g & $298.44^{\mathrm{a}}$ & $271.41^{\mathrm{b}}$ & 8.88 \\
Daily gain, g & 1.33 & 1.27 & 0.19 \\
SGR, \% & 1.81 & 1.77 & 0.016 \\
\hline
\end{tabular}

* Average in the same row having different superscripts differ significantly $P \unlhd 0.05$.

$* S E D$, standard error of a difference between 2 means $=\sqrt{ }(2 \times$ Error MS $/ r)$

\section{Feed utilization:}

Feed intake, feed conversion ratio (FCR) and survival rate of fish fed extruded diet type are shown in Table (4). Feed intake was significantly decreased with extruded floating diet. FCR values were significantly different between extruded diets $(\mathrm{P} \leq 0.05)$, the best FCR was recorded in EFD (extruded floating diets). The highest FCR was recorded with ESD (extruded sinking diets). Improved FCR on fish fed EFD compared with fish fed ESD is probably due to less feed consumed with high growth and fish was benefit of all diet that given at each meal if they are protected from birds. These results agree with that of Hematzade et al. (2013) with rainbow trout.

Table (4): Effect of extruded diet type on feed utilization of Nile tilapia reared in commercial earthen ponds.

\begin{tabular}{lccc}
\hline Parameters & \multicolumn{2}{c}{ Extruded diet } & SED \\
\cline { 2 - 3 } & Floating & Sinking & 9.71 \\
Feed intake, g/fish & $446.45^{\mathrm{b}}$ & $485.00^{\mathrm{a}}$ & 0.03 \\
FCR & $1.50^{\mathrm{b}}$ & $1.79^{\mathrm{a}}$ & 1.27 \\
Survival rate\% & $92.10^{\mathrm{a}}$ & $87.23^{\mathrm{b}}$ & 79.06 \\
Feed intake, kg/pond & $10275^{\mathrm{b}}$ & $10825^{\mathrm{a}}$ & \\
\hline
\end{tabular}

* Average in the same row having different superscripts differ significantly $P \leq 0.05$.

* SED, standard error of a difference between 2 means $=\sqrt{ }(2 \times$ Error MS/r $)$.

Usually, it is advantageous to feed a floating (extruded) feed, because the farmer can directly observe the feeding intensity of his fish. The use of floating diets saves about $25 \%$ of the feed that would otherwise be lost from the pond if sinking diets used (El-sayed, 2013).

Survival rates of Nile tilapia were 87.23 and $92.10 \%$ for ESD and EFD, respectively. These values are in the normal ranges as indicated by Teichert- Coddington and Green (1993), Knud-Hansen and Batterson (1994), Hassouna et al. (1998) and Abd El-Maksoud et al. (1999 a,b), Abouzied and Ali (2012) and Abouzied (2013) who reported values of tilapia survival rate ranged between 87 and $95 \%$. 


\section{Economic evaluation:}

The effect of extruded diet type on economic evaluation was shown in Table (5). Increased cost of ESD result of increased feed intake compared to EFD. Increase fish production on ponds fed EFD in a good growth rates significantly increased in final weight and increased the proportion of large fish (first and second grade in Marketing), which was characterized by rising selling prices with the low percentage of marketing small fish causing the high sales of fish fed on EFD compared with fish fed ESD.

Table (5): Effect of extruded diet type on economic efficiency of Nile tilapia reared in commercial earthen ponds.

\begin{tabular}{|c|c|c|c|}
\hline \multirow[t]{2}{*}{ Parameters } & \multicolumn{2}{|c|}{ Extruded diet } & \multirow[t]{2}{*}{ SED } \\
\hline & Floating & Sinking & \\
\hline \multicolumn{4}{|l|}{ Costs, L.E. /pond } \\
\hline Feed & $51375^{\mathrm{b}}$ & $54125^{\mathrm{a}}$ & 395 \\
\hline Fish & 1500 & 1500 & --- \\
\hline Other costs & 11150 & 11150 & --- \\
\hline Total costs & $64025^{\mathrm{b}}$ & $66772^{\mathrm{a}}$ & 395 \\
\hline \multicolumn{4}{|l|}{ Pond biomass, $\mathrm{kg}$} \\
\hline First grade & $5860^{\mathrm{a}}$ & $4625^{\mathrm{b}}$ & 300 \\
\hline Second grade & 825 & 800 & 218 \\
\hline Third grade & $305^{\mathrm{b}}$ & $750^{\mathrm{a}}$ & 5.52 \\
\hline Total fish selling price, L.E & $102500^{\mathrm{a}}$ & $88075^{b}$ & 3292 \\
\hline Net returns & $38475^{\mathrm{a}}$ & $21300^{\mathrm{b}}$ & 3275 \\
\hline Profit index & $1.98^{\mathrm{a}}$ & $1,63^{\mathrm{b}}$ & 0.005 \\
\hline
\end{tabular}

Price of one $\mathrm{kg}$ selling fish of first grade, 3 fish $/ \mathrm{kg}=15 \mathrm{L.E}$

Price of one $\mathrm{kg}$ selling fish of second grade, 4 fish $/ \mathrm{kg}=14 \mathrm{~L} . \mathrm{E}$

Price of one $\mathrm{kg}$ selling fish of third grade, in average $7 \mathrm{fish} / \mathrm{kg}=10 \mathrm{~L} . \mathrm{E}$

Price of $\mathrm{kg}$ feed $=5$ L.E.

$S E D$, standard error of a difference between 2 means $=\sqrt{ }(2 \times$ Error MS $/ r)$.

Feeding extruded floating diet lead to increase final body weight and improved fish graded at harvesting resulted improved net returns than extruded sinking diets. The total costs were 64025 and 66775 L.E /pond for the EFD and ESD, respectively. The corresponding values of net returns in L.E per pond were 38475 and 21300 , respectively.

Profit index were significantly differences $(\mathrm{P} \leq 0.05)$ and the values were 1.98 and 1.63 for EFD and ESD, respectively indicating that the highest returns were obtained with extruded floating diet.

In conclusion regarding to final weight, survival rate, net returns and profit index, the extruded floating diets was best feed if served suitable environmental condition specially low wind speed and lack of birds.

\section{REFERENCES}

Abd El-Maksoud, A.M.S; M.M.E. Hassouna; S.M. Allam; G.E. Aboul-Fotouh and M.Z.Y. ElShandaweily. (1999a). Effect of feeding regime on the performance of Nile tilapia (OreochromisniloticusL.) and grey mullet (MugilcephalusL.) reared in polyculture earthen ponds. Egyptian J. Nutr. and Feeds, 2: 111-121.

Abd El-Maksoud, A.M.S; M.M.E. Hassouna; S.M. Allam; G.E. Aboul-Fotouh and M.Z.Y. ElShandaweily. (1999b). Effect of fertilization with chicken manure on performance of Nile tilapia (OreochromisniloticusL.) and grey mullet (MugilcephalusL.) reared in polyculture earthen ponds. Egyptian J. Nutr. And Feeds, 2: 123-133.

Abdel- Hakim, N.F.; M. Bakeer and M.A. Rand Soltan (2000). Effect of two manuring systems on water quality and plankton communities in fishponds. Conference of Social and Agriculture Development of Sinai (D43-59): 47-158.

AbouZied, R.M. (2013). Effect of aeration systems and stocking density on growth performance, pond yield and economic impacts of Nile tilapia ((Oreochromisniloticus) reared in earthen ponds. Abbassa International Journal for Aquaculture, 6 (1): 213-228. 


\section{Abou-Zeid}

AbouZied, R.M. and A.A.A. Ali (2012). Effect of stocking density in intensive fish culture system on growth performance, feed utilization and economic productivity of Nile tilapia (OreochromisniloticusL.)reared in hapas. Abbassa International Journal for Aquaculture, 5 (1): 487 499.

Abu O.M.G.; L.O. Sanni; E.S. Erondu and O.A. Akinrotimi (2010). Economic viability of replacing maize with whole cassava root meal in the diet of Hybrid Cat-fish. Agric. J., 1: 1-5.

AOAC (1990). Official methods of analysis of the Association of Official Analytical Chemists, 15th edition. AOAC, Arlington, Virgina, USA.

Boyd, C.E. (1983). Water quality management for pond fish culture. Elsevier scientific publishing company, New York, 318pp.

Boyd, E.C. (1992). Water quality in warm water fish. Alabama Agric. Experiment station, Auburn Univ., Alabama.

Charo-Karisa, H.; H. Komen; S. Reynolds; M.A. Rezk; R.W. Ponzoni and H. Bovenhuis (2006). Genetic and environmental factors affecting growth of Nile tilapia (Oreochromisniloticus) juveniles: Modeling spatial correlations between hapas. Aquaculture, 255: 586-596.

Duncan, D.B. (1955). Multiple range and Multiple F test. Biometrics, 11: 1- 42.

Effiong B.N.; A. Sanni and J.O. Fakunle (2009). Effect of partial replacement of fishmeal with duckweed (Lemnapaucicostata) meal on the growth performance of Heterobranchuslongifilis fingerlings. Report Opin., 1(3):76-81.

El-Naggar, G.; A. Nasr-Alla and D.A. Al-Kenawy (2011). Egyptian aquaculture. Unpublished manuscript.

El-Sayed, A.F.M. (1999). Aquaculture feed and fertilizer resource Atlas of Egypt. FAO, Regional Office for the Near East, Cairo, Egypt (105 pp.).

El-Sayed, A.F.M. (2007). Analysis of feeds and fertilizers for sustainable aquaculture development in Egypt. 2007. In M.R. Hasan, T. Hecht, S.S. De Silva \& A.G.J. Tacon, eds. Study and analysis of feeds and fertilizers for sustainable aquaculture development, pp 401-422. FAO Fisheries Technical Paper No. 497, Rome, FAO. 510 pp.

El-Sayed, A.F.M. (2013). On-farm feed management practices for Nile tilapia (Oreochromisniloticus) in Egypt. In M.R. Hasan and M.B. New, eds. On-farm feeding and feed management in aquaculture. FAO Fisheries and Aquaculture Technical Paper No. 583.Rome, FAO, pp. 101-129.

El-Sayed, A.M.; M. Dickson and G.O. El-Naggar (2015). Value chain analysis of the aquaculture feed sector in Egypt. Aquaculture, 437: 92-101.

European Inland Fisheries Advisory Commission (1993). Water quality criteria for European fresh water fish. Report on Ammonia and Inland Fisheries. Water Res., 7: 1011-1011.

FAO (2012). Food and Agriculture Organization of the United Nations. The state of world fisheries and aquaculture 2012. Rome, Italy: FAO.

FAO (2013). FAO STAT. http://faostat.fao.org/site/339/default.aspx.

Florida Department of Environmental Protection (2001). Calculation of un-ionized ammonia in fresh water: Storet Parameter Code 00619. Tallahassee, FL: Florida Department of Environmental Protection. Final report. Pp 16.

GAFRD (2012). General Authority for Fisheries Resources Development. Fisheries Statistics Year Book, Cairo, Egypt.

GAFRD (2014). General Authority for Fisheries Resources Development. Fisheries Statistics Year Book 2012. GAFRD, Ministry of Agriculture and Land Reclamation, Cairo, Egypt.

Hassouna, M.M.E; A.M.S. Abd El-Maksoud; M.S.R. Radwan and A.A. Abd El-Rahman (1998). Evaluation of three commercial feeding regimes for Nile tilapia, OreochromisniloticusL., reared in earthen ponds. The 10 ${ }^{\text {th }}$ Conf. Egyptian Soc., Anim. Prod. Assiut., Egypt, 13-15 December, 35: 267277.

Hematzade, A.; M.M. Taati and M. Raissy (2013). Effects of extrusion of diet on growth parameters of rainbow trout (Oncorhynchusmykiss). ABAH Bioflux, 5(2):127-131. 
Jobling, M. (1983). A short review and critique of methodology used in fish growth and nutrition studies.J. Fish. Biol, 23: 685-703.

Khalfalla, M.M.; Y.A. Hammouda; A.M. Tahoun and H.A.M. Abo-State (2008). Effect of broodstock sex ratio on growth and reproductive performance of blue tilapia OreochromisAueus (Steindachner) reared in hapas. Proceedings of the 8th International Symposium on Tilapia in Aquaculture, October 12-14, 2008, The Central Laboratory for Aquaculture Research, Cairo, Egypt, pp: 115-125.

Knud-Hansen, C.F. and T.R. Batterson (1994). Effect of fertilization frequency on the production of nile tilapia (Oreochromisnitolicus). Aquaculture, 123: 271-280.

Kristiansen, T.S. and A. Ferno (2007). Individual behaviour and growth of halibut (Hippoglossushippoglossus L.) fed sinking and floating feed: Evidence of different coping styles. Applied Animal Behaviour Science, 104: 236-250.

Macfadyen, G.; A.M. Nasr-Alla; D.A. Kenawy; M. Fathi; H. Hebicha; A.M. Diab; S.M. Hussein; R.M. Abouzied and G.O. El Naggar (2011). Value-chain analysis of Egyptian aquaculture. Project Report 2011-54. The WorldFish Center. Penang, Malaysia. 84 pp.

Macfadyen, G.; A.M. Nasr-Alla; D.A. Kenawy; M. Fathi; H. Hebicha; A.M. Diab; S.M. Hussein; R.M. Abouzied and G.O. El Naggar (2012). Value-chain analysis - An assessment methodology to estimate Egyptian aquaculture sector performance. Aquaculture, 362-363 pp. 18-27.

NRC (1993). Nutrient requirement of fish. National Academy Press, Washington DC.

SPSS (2012). Statistical Package For Social Science (for Windows). Release 21 Copyright (C), SPSS Inc., Chicago, USA.

Stickney, R. (1986). Culture of Nonsalmonid Freshwater Fishes. CRC Press, BocaRaton, Florida, 201 pp.

Tahoun, A.M.A. (2007). Studies on some factors affecting the production and reproduction of Nile tilapia . Ph.D. Thesis, University of Kafr El-Sheikh, Egypt.

Teichert-Coddington, D. and B.W. Green (1993). Tilapias yield improvement through maintenance of minimal oxygen concentrations in experimental grow-out ponds in Honduras. Aquaculture, 118: 6371. 
تأثثير نوع العليقة المبثوقة على مظاهر النمو والاستفادة من الغذاء والكفاءة الاقتصادية للبلطى النيلى فى المزارع

رمضان محمد ابوزيد

قسم الانتاج الحيوانس- كلية الزرراعة - جامعة الفيوم- جمهورية مصر العربية.

هدفت هذه الدراسة الى تقييم تأثير نوع العليقة المبثوقة (طافية او غاطسة) علنظظاهر النمو و الاستفادة من الغذاء و الكفاءة الاقتصادية

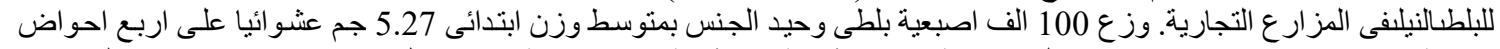

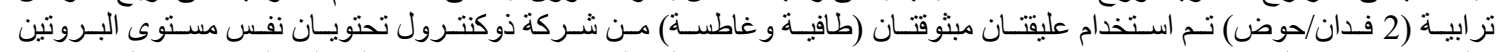

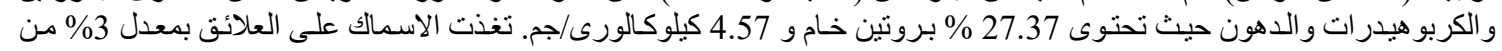
الوزن علت كل شهر حتى الحصاد.

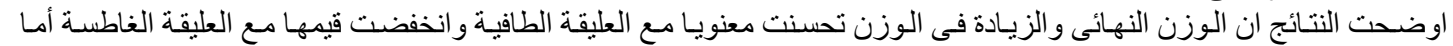

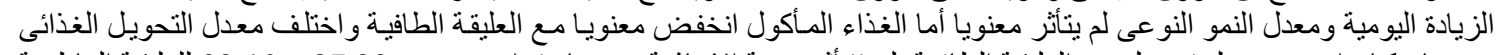

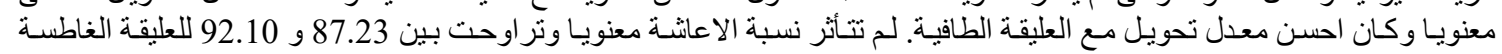

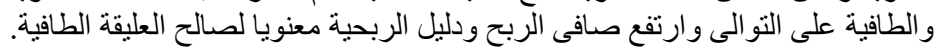

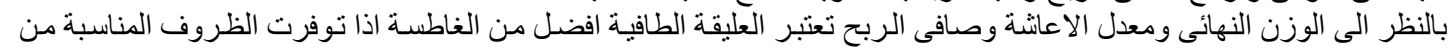
حيث انخفاض او عدم وجود رياح او طيور 